\title{
WYBRANE KARTY Z DZIEJÓW WOLBORZA. MATERIAŁY Z KONFERENCJI NAUKOWEJ Z OKAZJI 950-LECIA MIASTA (10 X 2015). RED. MARIA WICHOWA. ŁÓDŹ 2016
}

\section{SŁOWA KLUCZOWE}

Wolbórz, dzieje miasta, recenzja

Recenzowana książka to pokłosie czwartej z kolei konferencji naukowej, która odbyła się w Wolborzu, zorganizowanej 10 października 2015 r. z okazji jubileuszu 950-lecia tego miasta. Wysiłek organizacyjny podjęli burmistrz Wolborza, Rada Miejska, Stowarzyszenie Przyjaciół Wolborza i Miejskiego Ośrodka Kultury oraz Łódzkie Towarzystwo Naukowe. Materiały pokonferencyjne zebrała i zredagowała profesor Maria Wichowa.

$\mathrm{Na}$ tom składa się słowo wstępne pióra profesor Wichowej oraz dziesięć artykułów. Każdy z referatów zawiera bibliografię załącznikową oraz streszczenie w języku angielskim. Tom przygotowano z należytą pieczołowitością. Opatrzono go przejrzystym spisem treści, indeksem nazwisk, dołączono również wkładkę z bogatym materiałem ilustracyjnym.

Tom otwiera wstęp redaktorki, który zarazem stanowi esej o formie uobecnienia ludzi żyjących przed wiekami. Tekst o „wysiłku przywoływania pamięci” otwierają i zamykają rozważania św. Augustyna. Tym samym redaktorka wprowadza czytelników w lekturę recenzowanej książki, przywołując w porządku chronologicznym wcześniejsze konferencje organizowane w Wolborzu, poświęcone

Monika Sulejewicz-Nowicka - dr, Biblioteka Uniwersytetu Łódzkiego, Uniwersytet Łódzki, ul. Matejki 32/38, 90-001 Łódź; e-mail: monika-sn-dm@wp.pl 
postaci i dorobkowi intelektualnemu najwybitniejszego wolborzanina, a mianowicie Andrzeja Frycza Modrzewskiego. Ponadto wskazuje cel prac redakcyjnych i w sposób obiektywny poleca uwadze czytelnika zamieszczone w tomie studia, które albo dotyczą dziejów Wolborza, albo stanowią wypowiedzi o Wolborzu współczesnym.

Pierwszą grupę referatów tworzą prace o historii miasta. Autorzy: Zofia Wilk-Woś, Tomasz Stolarczyk, Waldemar Gliński, Maria Wichowa, Wanda Nalepa Amarantodou, Anna i Krzysztof Wardowie sięgnęli do materiałów źródłowych.

Profesor Zofia Wilk-Woś omówiła nieznane i mało znane fakty z dziejów średniowiecznego Wolborza, przypomniała początki nieistniejącego już zamku wolborskiego. Podjęła temat życia intelektualnego humanistów skupionych wokół biskupa Piotra z Bnina; szczególnie upodobał on sobie wolborski zamek, który za jego pontyfikatu stał się prężnym ośrodkiem renesansowych idei. Chętnie gościli w nim bowiem: Mikołaj Wodka z Kwidzyna, Jan Heydecke-Miryka, Bernardyn Gallus z Zadaru, Maciej Drzewicki i Filip Kallimach. To tutaj, w jadalni zimowej, toczyły się dyskusje o polityce, filozofii, literaturze i sztuce.

Z kolei doktor Tomasz Stolarczyk opisał życie społeczne i gospodarcze wolborzan na podstawie wnikliwej analizy średniowiecznych dokumentów dotyczących przywilejów monarszych, tj. falsyfikatu mogileńskiego z 1065 r. i bulli gnieźnieńskiej z 1136 r. oraz poźniejszych szesnatowiecznych inwentarzy dóbr i dochodów biskupstwa włocławskiego. Z przeanalizowanych przez badacza źródeł wyłonił się obraz miejscowości prężnie rozwijającej się, która ze wsi przerodziła się w miasto liczące pod koniec XVI w. 2800 mieszkańców.

Dzieje parafii św. Mikołaja w Wolborzu od jej powstania aż do XX w. przypomniał zaś ksiądz profesor Waldemar Gliński. Na podstawie drukowanych i rękopiśmiennych źródeł historycznych omówił jej początki, historię, wygląd, zasięg, zabytki świątyni oraz sporządził zestawienie liczebności wiernych w poszczególnych miejscowościach i katalog proboszczów. Jak zaznaczyła we wstępie redaktorka - to „pierwsze tak poważne studium o dziejach wolborskiej kolegiaty”. Być może zainspiruje ono badaczy do dalszych studiów nad kościelnymi dziejami miejscowości.

Życiem intelektualnym Wolbrza w XV i XVI w. zajęła się profesor Maria Wichowa. W recenzowanym tomie zamieściła dwa artykuły.

W pierwszym pokazała miasto jako ośrodek renesansowego humanizmu. $\mathrm{Na}$ podstawie szczątkowych źródeł opisała działalność kulturotwórczą kolonii Akademii Krakowskiej i omówiła sylwetki wolborzan uprawiających działalność naukową oraz niektórych profesorów (Marcina z Wolborza, nauczyciela poetyki, Adama z Wolborza, autora traktatu epistolograficznego i Józefa Wawrzyńca Sałtszewicza, profesora astrologii i teologii). Zrekonstruowała wiedzę o kilkakrotnym pobycie 
wybitnego poety Filipa Kallimacha w Wolborzu i o jego przyjaznych stosunkach z biskupem Piotrem z Bnina. Jednocześnie udowodniła, że koniec średniowiecza w Polsce należałoby przesunąć na I połowę wieku XV. To niezwykle cenne odkrycie badawcze. Przedstawione fakty nie były dotąd przedmiotem badań uczonych zajmujących się przeszłością Wolborza.

W drugim tekście profesor Wichowa po raz kolejny podjęła się ważnego zadania, albowiem jako pierwsza przedstawiła pełne opracowanie związków Jędrzeja Kitowicza z Wolborzem. Do tej pory wiedza na ten temat była fragmentaryczna, a nawet szczątkowa. Warto podkreślić, że biografia pisarza jest z trudem rekonstruowana przez badaczy, a autorka sięgnęła do źródeł rękopiśmiennych i drukowanych. Redaktorka tomu omówiła m.in. pobyt autora Opisu obyczajów za panowania Augusta III na służbie u biskupa kujawskiego Antoniego Ostrowskiego, pracę administracyjną i jego obowiązki kantora.

Rekonstrukcją biografii wybitnego pisarza, autora traktatu O poprawie Rzeczypospolitej - wolborzanina - zajęła się również doktor Wanda Nalepa Amarantidou. Tym razem przypomniano znany, choć traktowany przez badaczy marginalnie, epizod trzepnicki w życiu i twórczości Andrzeja Frycza Modrzewskiego.

Część historyczną zamyka wspólne studium profesorów z łódzkiego ośrodka akademickiego. Anna i Krzysztof Wardowie wnikliwie omówili przywileje i powinności rzemieślników w dawnym Wolborzu, analizując dogłębnie w oparciu o fachową literaturę przedmiotu dokument wystawiony w 1617 r. przez biskupa Pawła Wołuckiego. Liczba rzemieślników w dawnym Wolborzu reprezentujących różne profesje, tj. rzeźnictwo, piekarstwo, szewstwo, sukiennictwo i piwowarstwo, oraz ich aktywność w znacznej mierze przyczyniła się do rozwoju miasta, do tego stopnia, że wzorem innych wiodących wówczas grodów, takich jak Wrocław, Kraków, Gdańsk, Lwów, Poznań, Toruń, Lublin, wolborscy rzemieślnicy zaczęli organizować cechy.

W dalszej części omawianej tu książki zamieszczone zostały prace, które współczesnemu Wolborzowi poświęcili: Zenon Puchała, Teresa Duda i Urszula Wich-Szymczak.

Zenon Puchała - historyk, wieloletni działacz Stowarzyszenia Przyjaciół Wolborza - opracował biografię wybitnego wolborzanina, doktora nauk medycznych, społecznika zgłębiającego i popularyzującego wiedzę o dziejach swojego miasta, Stefana Siniarskiego. Warto podkreślić, że to jego pierwsza biografia przeznaczona do druku.

Natomiast wieloletnia przewodnicząca SPW - Teresa Duda - opisała pół wieku działalności Stowarzyszenia powołanego w 1963 r., jego historię, najwybitniejszych członków i stałe punkty działalności.

Tę część zamyka studium doktor Urszuli Wich-Szymczak o kreowaniu wizerunku Wolborza z wykorzystaniem narzędzi online. Autorka zbadała cele 
i narzędzia strategii marketingowych niezbędnych przy promocji miasta w mediach społecznościowych na przykładzie Facebooka. Badaczka, na podstawie przeprowadzonych analiz w dwóch okresach: we wrześniu-październiku 2015 r. i w lutym-marcu 2016 r., wysunęła konkretne wnioski, niezmiernie ważne przede wszystkim dla władz miasta. Pokazała bowiem, jak stworzyć jego koherentny wizerunek offline, który przemawiałby zarówno do mieszkańców, jak i do turystów i inwestorów. W tym celu - jak zaleca - należy nakreślić długotrwały plan komunikacyjny, zaangażować wolborzan, którzy swoją aktywnością kreują życie miejscowości i przeprowadzić kampanię komunikacyjną. Jednocześnie władze miasta winny przede wszystkim nawiązywać relacje z mediami i je monitorować, gdyż na podstawie dobrego monitoringu interakcji w serwisach społecznościowych można stwierdzić, czy strategie marketingowe i PR-owe rzeczywiście są realizowane i czy robione jest to w sposób odpowiedni, gdyż, jak podkreśliła badaczka, social media to nie serwis informacyjny, a platforma komunikacyjna.

Recenzowany tom materiałów pokonferencyjnych to zbiór tekstów dwojakiego rodzaju. Część z nich dotyczy historii Wolborza, a część jego dziejów współczesnych. Wszystkie prace charakteryzują się wysokim poziomem naukowym, logicznym i spójnym wywodem, zadbano także o ich językową stronę.

Twórcy zamieszczonych studiów to albo wolborzanie, albo osoby związane z tym miastem lub pasjonaci i fachowcy w swoich dyscyplinach naukowych, którzy nie boją się podejmować wyzwań badawczych. Stąd też zajęli się opracowaniem zagadnień ważnych dla naświetlenia dziejów miasta, wypełnienia luk w jego historii czy też rozwiania towarzyszących im niejasności. Często okazywało się, że to tematy traktowane przez uczonych marginalnie, przygodnie, a niekiedy pokazywane do tej pory w niewłaściwym świetle. Badacze prezentowanych prac poszerzyli więc, fragmentaryczną jak dotąd wiedzę, o życiu społecznym, gospodarczym $\mathrm{i}$ intelektualnym miasta $\mathrm{w}$ wiekach średnich i w okresie renesansu, wykazując, że Wolbórz stanowił w istocie centrum życia umysłowego i gospodarczego - to tutaj przez zamek biskupi przewijała się elita tamtych czasów, to tutaj powoływano cechy rzemieślnicze, nadając im znaczące przywileje. Niejednokrotnie autorzy poszczególnych studiów wydobywali interesujące szczegóły o roli biskupów czy władców dbających o rozwój miasta, ponadto rekonstruowali biografie wybitnych ludzi, którzy na tej ziemi żyli i stanowili jej chlubę. Zagadnienia omówili zaś bardzo erudycyjnie i w sposób wyczerpujący, siegając do materiałów źródłowych, archiwalnych, drukowanych i rękopiśmiennych, tekstów literackich i paraliterackich, narzędzi online. 
Monika Sulejewicz-Nowicka

\title{
WYBRANE KARTY Z DZIEJÓW WOLBORZA. MATERIAŁY Z KONFERENCJI NAUKOWEJ Z OKAZJI 950-LECIA MIASTA (10 X 2015) EDITED BY MARIA WICHOWA. ŁÓDŹ 2016
}

\author{
(summary)
}

The reviewed volume of post-conference materials is a collection of two types of texts: about the past history of Wolborz, and about of its contemporary history. All works are characterized a high level of scientific and logical and consistent argument. The authors have developed important issues regarding the social, economic and intellectual life of Wolborz in the Middle Ages and during the Renaissance. Also, the researchers reconstructed the biographies of outstanding citizens of Wolborz. They used source, archival, printed and manuscript materials, literary and para-literary texts and online tools.

\section{KEYWORDS}

Wolborz, the story of city, review 
